\title{
Inkluzivno obrazovanje i dimenzija jednakosti u nastavi vjeronauka
}

\author{
Aleksandra Krampač Grljušić ${ }^{*}$ \\ a.krampac@yahoo.com \\ http://orcid.org/0000-0002-3781-6439 \\ Dalibor Adžić**: \\ dalibor.adzic@azoo.hr \\ http://orcid.org/0000-0001-6280-3077
}

https://doi.org/10.31192/np.18.1.6

UDK: 376-056.36:342.7

27-752:376-056.36

Pregledni članak / Review

Primljeno: 3. veljače 2019. Prihvaćeno: 21. studenog 2019.

\author{
Aleksandra Gvozdanović Debeljak*** \\ agdebeljak@mefos.hr \\ http://orcid.org/0000-0001-9348-4371
}

Inkluzivna škola rezultat je različitih djelovanja društva. Da bi djeca s teškoćama u razvoju bila uspješno uključena u obrazovnu praksu, važno je razviti svijest djece o prihvaćanju i poštivanju različitosti. Pretraživanjem relevantne literature u radu prikazane su zakonske odredbe vezane uz odgoj i obrazovanje učenika s teškoćama u razvoju, nova i stara paradigma invaliditeta $i$ inkluzivna edukacija s naglaskom na nastavu vjeronauka. Inkluzivno obrazovanje usmjereno je na uvažavanje potreba svakog djeteta. Nova paradigma slijedi Konvenciju o pravima osoba s invaliditetom koja prije svega ističe poštivanje ljudskih prava. Poštivanje, uvažavanje i prihvaćanje različitosti u inkluzivnoj školi temelji su svakog nastavnog predmeta $i$ učitelja. Budući da školski vjeronauk kroz svoj program ističe važnost i jednakost svih ljudi, vjeroučitelj je važan kreator programa nastave vjeronauka koja doprinosi inkluzivnom obrazovanju. Ključne riječi: djeca s teškoćama, inkluzija, ljudska prava, obrazovanje, školski vjeronauk.

\footnotetext{
* Dr. sc. Aleksandra Krampač-Grljušić, ravnateljica Osnovna škola Ljudevita Gaja Osijek, Krstova ulica 99, HR-31000 Osijek.

** Dalibor Adžić, mag. relig. pedag. i kateh., Agencija za odgoj i obrazovanje - Podružnica Osijek, Strossmayerova 6/1, HR-31000 Osijek.

**: Aleksandra Gvozdanović Debeljak, mag. prim. educ., mag. razredne nastave s defektologijom, doktorandica, Sveučilište u Zagrebu, Edukacijsko-rehabilitacijski fakultet, Borongajska cesta 83f, HR-10000 Zagreb; Osnovna škola Ljudevita Gaja Osijek, Krstova ulica 99, HR31000 Osijek.
} 


\section{Uvod}

Inkluzivno obrazovanje proizlazi iz prava na obrazovanje, što je jedno od osnovnih ljudskih prava. ${ }^{1}$ Velik broj djece $\mathrm{s}$ teškoćama ne polazi inkluzivne škole sa svojim vršnjacima ili ne dobiva odgovarajuću podršku. Takvo obrazovanje priprema djecu s teškoćama za život u segregaciji i izolaciji. Edukacijsko uključivanje djece s teškoćama u redovni sustav odgoja i obrazovanja povećava priliku da djeca s teškoćama steknu teorijska i praktična (društvena) znanja kao i njihovi vršnjaci ${ }^{2}$ i donosi nove izazove kao što su: socijalna prihvaćenost djece s teškoćama u redovitoj školi, kompetentnost učitelja, suradnja svih čimbenika radi podrške djetetu i sl. Za uspješno uključivanje u obrazovnu praksu važno je razviti svijest djece o prihvaćanju i poštivanju različitosti. Da bi inkluzija bila kvalitetnija, zahtijevaju se društvene promjene kao i promjene vlastitih stavova, uvjerenja, znanja i vještina. ${ }^{3}$

Sastavnice religiozne kompetencije koje su temelj vjeronauka kao školskog predmeta i vjeronaučnog programa ${ }^{4}$ ističu značenje razumijevanja, poznavanja i osviještenosti, što je put prema inkluzivnom obrazovanju.

»U najnovijem dokumentu HBK odgoju, u posebnom poglavlju Vjerski odgoj osoba s teškoćama u razvoju, ističe se da unatoč brojnim nastojanjima ima još uvijek dosta neriješenih pitanja inkluzije ili integrativne pedagogije u školskom sustavu, ali i cjelovitog uključivanja u život šire društvene zajednice osoba s teškoćama. Posebno se naglašava potreba jače zauzetosti na području inkluzije službenika Crkve, svećenika i laika. Pohvaljuju se na tom polju napori građanskih udruga i inicijativa. $\aleph^{5}$

\section{Djeca s teškoćama u Republici Hrvatskoj}

Uključivanje učenika s teškoćama u redovne osnovne škole Republike $\mathrm{Hr}$ vatske započelo je 1980-ih godina, a odgoj i obrazovanje učenika s teškoćama postalo sastavni dio školskog sustava. ${ }^{6}$ Suvremena hrvatska škola omogućuje

${ }^{1}$ Usp. UJEDINJENI NARODI, Opća deklaracija o ljudskim pravima, https://www.pariter.hr/ wp-content/uploads/2014/10/opca_deklaracija_o_ljudskim-pravima.pdf (04.01.2019), 6.

${ }^{2}$ Usp. A. GUSTAVSSON, Delaktighetens språk (the language of participation), Lund, Studentlitteratur, 2004, prema M. B. BRONSON, P. HAUSER-CRAM, M. E. WARFIELD, Classroom behaviors of preschool children with and without developmental disabilities, Journal of Applied Developmental Psychology, 16 (1995) 3, 371-390.

${ }^{3}$ Usp. Đ. IVANČIĆ, Z. STANČIĆ, Stvaranje inkluzivne kulture škole, Hrvatska revija za rehabilitacijska istraživanja, 49 (2013) 2, 139-157, 149.

${ }^{4}$ Usp. T. A. FILIPOVIĆ, Vjeronauk u školi pred zahtjevima vrednovanja, Nova prisutnost, 7 (2009) 2, 245-263, 261.

${ }^{5}$ HRVATSKA BISKUPSKA KONFERENCIJA, »Da vaša radost bude potpuna $(I v 15,11)$. Kateheza i rast u vjeri u današnjim okolnostima, Zagreb, Kršćanska sadašnjost, 2018, 54-55.

${ }^{6}$ Usp. Organizacija za ekonomsku suradnju i razvoj, Obrazovne politike za učenike u riziku i učenike s teškoćama u razvoju u jugoistočnoj Europi Hrvatska, 2007; http://www.oecd.org/ 
i potiče uključivanje učenika s teškoćama u redoviti školski sustav u ovisnosti o: vrsti i stupnju teškoće, procjeni posebne odgojno-obrazovne podrške koju učenici s teškoćama trebaju, odnosno o uvjetima koje pruža škola i omogućuje lokalna zajednica. ${ }^{7}$ Primjereni programi školovanja ostvaruju se: u redovitome razrednom odjelu, dijelom u redovitom, a dijelom u posebnom razrednom odjelu, posebnom razrednom odjelu te odgojno obrazovnoj skupini. ${ }^{8}$ Školovanje učenika s teškoćama u redovitom školskom sustavu može se odvijati prema: redovitom programu uz individualizirane postupke; redovitom programu uz prilagodbu sadržaja i individualizirane postupke; posebnom programu uz individualizirane postupke. ${ }^{9}$

\section{Obrazovanje bez diskriminacije}

Zakonom je određeno da su osobe s invaliditetom (i djeca s teškoćama u razvoju) ravnopravni članovi društva, što obvezuje društvo na uvažavanje prava djece s teškoćama (npr. prava na obrazovanje). Ostvarivanjem tih prava društvo ostvaruje svoje inkluzivne ciljeve. ${ }^{10}$

Djeca $\mathrm{s}$ teškoćama imaju pravo na obrazovanje na ravnopravnoj osnovi $\mathrm{s}$ drugima u zajednici, bez diskriminacije zbog invaliditeta. ${ }^{11}$ Diskriminacija »na osnovi invaliditeta« znači bilo kakvo razlikovanje, isključivanje ili ograničavanje zbog invaliditeta. To uključuje sve oblike diskriminacije, uključujući i uskraćivanje razumne prilagodbe. ${ }^{12} \mathrm{U}$ obrazovanju »razumna prilagodba « znači ostvarivanje osnovnih ljudskih prava bez diskriminacije na temelju teškoća. Odgojno-obrazovne ustanove i materijali trebali bi biti dostupni djeci s teškoćama, a prijevoz osiguran kao i uključujući kurikulum i modeli poučavanja. ${ }^{13}$

Postoji politički vakuum u vodstvu i odgovornosti za inkluzivno obrazovanje. Djeca s teškoćama često ostaju nevidljiva za odgojno-obrazovni sustav, a njihove obitelji nisu podržane. ${ }^{14}$ Roditelji djece s teškoćama od stručnjaka traže uvažavanje i priznavanje njihove djece i njihovih roditeljskih sposobnosti i znanja. Uloga roditelja je zahtjevna i teška, kao i uloga stručnjaka, te je ključno

\footnotetext{
dataoecd/17/26/38614202.pdf (04.01.2019).

7 Usp. Nastavni plan i program za osnovnu školu (Narodne novine, 102/06).

${ }^{8}$ Usp. Pravilnik o osnovnoškolskom i srednjoškolskom odgoju i obrazovanju učenika s teškoćama u razvoju (Narodne novine, 23/91, 24/15), čl. 3, st. 5.

${ }_{9}$ Usp. isto, čl. 3, st. 4.

${ }^{10}$ Usp. A. GVOZDANOVIĆ DEBELJAK, B. BARABAN, R. LOVRIĆ, Glasovanje osoba s intelektualnim teškoćama u kontekstu temeljnih ljudskih vrijednosti, Nova prisutnost, 16 (2018) 2, 229-245, 245.

${ }^{11}$ Usp. Ujedinjeni narodi, Konvencija o pravima osoba s invaliditetom, New York, 2006, čl. 7 i 24.

${ }^{12}$ Usp. isto, čl. 2 i 5.

${ }^{13}$ Usp. INICO (Inclusion International), Better education for all. When we're included too, Salamanca, Instituto Universitario de Integracio'n en la Comunidad, 2009.

${ }^{14}$ Ujedinjeni narodi, Konvencija o pravima osoba..., čl. 24.2.
} 
ostvariti uspješnu komunikaciju. ${ }^{15}$ Članovi obitelji i roditelji važni su partneri u odgojno-obrazovnom procesu djece s teškoćama. Komunikacija stručnjaka i roditelja treba biti otvorena, stalna da bi se postiglo međusobno razumijevanje i ostvarili zajednički ciljevi. ${ }^{16}$

Inkluzivno obrazovanje je pravo, ali unatoč tome više od $5 \%$ djece s teškoćama završi samo osnovnu školu. ${ }^{17}$ Konvencija o pravima osoba s invaliditetom prepoznaje da osobe s invaliditetom imaju pravo na potpunu i učinkovitu inkluziju i sudjelovanje u zajednici u svim područjima života, uključujući i obrazovanje.

\subsection{Stara i nova paradigma invaliditeta}

Unatoč brojnim značajnim zakonskim promjenama osobama s invaliditetom ne jamči se stvarna jednakost u svakodnevnom životu. Različiti sustavi zaštite i djelovanja prema osobama s invaliditetom različito definiraju teškoću i naglašavaju one aspekte problema koji su prioritetni za vlastito određenje. ${ }^{18} \mathrm{U}$ medicinskom modelu osoba s invaliditetom shvaća se kao problem. ${ }^{19} \mathrm{U}$ prvom planu je nedostatak, oštećenje i teškoća, a temeljni je cilj rehabilitacije promjena i »popravljanje« osobe. Stara paradigma invaliditeta određuje invaliditet kao nedostatak unutar osobe koji je rezultat funkcionalnog poremećaja povezanog sa svakodnevnim aktivnostima. ${ }^{20}$

Medicinski model sedamdesetih godina 20. stoljeća kritizirale su mnoge aktivističke skupine koje su se borile za ljudska prava, ponajprije osoba s invaliditetom. Rezultat tih borbi bilo je uvođenje novog modela. Medicinski pristup zamijenio se »socijalnim modelom«.

»Na taj je način omogućen nov, drugačiji pristup, kao i uvid u potrebe osoba s invaliditetom na mnogim područjima, ne samo medicine, već i ostalih profesija. U okviru takvog pristupa neovisnost razumijeva osobu koja može sama zadovoljavati svoje potrebe, djelotvorno preuzimajući kontrolu nad svojim životom odabirući kako će taj život izgledati..121

\footnotetext{
${ }^{15}$ Usp. H. DAVIS, Pomozimo bolesnoj djeci, Jastrebarsko, Naklada Slap, 1998, 30-31.

${ }^{16}$ Usp. M. KOSTELNIK i dr., Djeca s posebnim potrebama. Priručnik za odgajatelje, učitelje $i$ roditelje, s engl. prev. M. Varlandy Supek, Zagreb, Educa, 2004, 21-22.

${ }^{17}$ Usp. INICO, Better education for all...

${ }^{18}$ Usp. Z. ŠOSTAR i dr., Položaj osoba s invaliditetom u Gradu Zagrebu, Revija za socijalnu politiku, 13 (2006) 1, 53-65.

${ }^{19}$ Usp. B. TEODOROVIĆ, D. BRATKOVIĆ, Osobe s teškoćama u razvoju u sustavu socijalne skrbi, Revija za socijalnu politiku, 8 (2001) 3-4, 279-290.

${ }^{20}$ Usp. A. P. TURNBULL, H. R. TURNBULL, From the old to the new paradigm of disability and families. Research to enhance family quality of life outcomes, u: J. PAUL, C. D. LAVELY, A. CRANSTON-GINGRAS (ur.), Professional issues in special education: Intellectual, ethical, and professional challenges to the profession, Westport, Greenwood Publishing Group, 2002, 83-117.

${ }^{21}$ Isto..., 74.
} 
»Socijalni model« stavlja pojedinca u centar odlučivanja pri donošenju odluka koje se odnose na njega i smješta problem izvan osobe, $u$ društvo. ${ }^{22}$ Nova paradigma obilježava teškoću kao kontekstualnu i društvenu, te ističe "popravljanje« sustava.

»Prisutnost medicinskog modela i odgovarajućeg načina razmišljanja o razlikama i različitosti još je uvijek itekako vidljiva kroz usvajanje zakona kojima se osobama s invaliditetom osiguravaju određena prava na temelju 'onoga što one ne mogu', a ne na temelju onoga što bi, u skladu sa suvremenim shvaćanjem osnovnih ljudskih prava, mogle, željele i trebale. « $^{23}$

Konvencija o pravima osoba s invaliditetom (2006.) uvažava novu paradigmu i ide dalje u poštivanju ljudskih prava. To je pravičan i pravedan dokument za sve građane (pravičan jer se odnosi na uvažavanje svih građana kao jednakih, a pravedan kada bi se stvarno primjenjivao).

\subsection{Uključivanje djece s teškoćama u sustav odgoja i obrazovanja}

Međunarodna politika i zakoni potvrđuju koncept inkluzivnog obrazovanja. Uvažavanje različitosti u razrednom okruženju i u sklopu svakog nastavnog procesa odašilje djetetu poruku prihvaćenosti, uvažavanja i želje za podrškom, a pripadanje je iznimno važno za svako dijete i njegov zdrav rast i razvoj.

Prvi pokušaj da se djeca s teškoćama obrazuju u istoj učionici sa svojim vršnjacima nazvan je integracija. Pomak se očitovao u otvaranju redovite škole prema djeci s teškoćama, a posebne odgojno-obrazovne ustanove prestale su biti jedino mjesto njihova obrazovanja. Redovite škole osnivale su posebne odjele za djecu s teškoćama, što je dovelo do fizičkog odvajanja od njihovih tipičnih vršnjaka u redovnim odjelima. Integrirano obrazovanje zahtijeva da se učenik prilagodi potrebama škole, a inkluzivno obrazovanje da se škole prilagode potrebama učenika s teškoćama.

\section{Vjerski odgoj - inkluzivni model obrazovanja}

Religiozni odgoj, općenito, u prošlom stoljeću je više shvaćen kao intelektualni prijenos vjerskih sadržaja i moralnih normi, u svojoj transformaciji sada se više i jasnije shvaća kao osobni primjer i osobni suodnos s odgajanikom u

\footnotetext{
${ }^{22}$ Usp. G. QUINN, T. DEGENER, The moral authority for change: human rights values and the worldwide process of disability reform, u: G. Quinn i dr. (ur.), Human Rights and Disability. The current use and future potential of United Nations human rights instruments in the context of disability, New York - Geneva, United Nations, 2002; www.unhchr.ch/disability/part1. htm\#chapter1.pdf (17.06.2019).

${ }^{23}$ Usp. K. URBANC, Medicinski, socijalni ili neomedicinski pristup skrbi za osobe s invaliditetom, Ljetopis socijalnog rada, 12 (2005) 2, 321-333, (3).
} 
prenošenju kršćanske dimenzije života. Tako onda i kateheza - vjerska pouka, vjeronauk - osim u redovitim uvjetima odgoja i obrazovanja na poseban način vodi računa o učenicima-vjeroučenicima u velikom spektru njihovih teškoća i potreba i odgovarajućim katehetskim modelima i pristupima koji su u najvećoj mogućoj mjeri poosobljeni i prilagođeni. Takvi modeli, iako diferencirani prema stupnju ili kategoriji poteškoće, imaju uvijek za polazište uključenost učenika s teškoćama u konkretnu životnu zajednicu i okolinu. Svakako je u fokusu i stručno, odgojno, pedagoško osposobljavanje odgojitelja-vjeroučitelja da mogu što kvalitetnije i stručnije prionuti zadatcima koje zahtjevan rad u takvim okolnostima od njih traži. Odgoj vjere za takve kategorije učenika mora njegovati motivacijske čimbenike, prepoznati njihov osjećajni razvoj, dosegnuti njihovu osjećajnu osobnost. Dakle, razvijati njihovu vlastitu osobnost i u vjeri bez obzira na sve objektivne ili subjektivne remetilačke čimbenike. U drugoj polovici dvadesetog stoljeća u različitim zemljama nastaju ozbiljni pokušaji da se razviju prikladne metode poučavanja djece s teškoćama. Među njima se posebno ističe i razvoj metode Vivre. Poseban karakter tako osmišljene i postavljene vjerske pouke je strukturiranje didaktičkog programa usmjerenog na bit kršćanke poruke. Posredovanje u prenošenju te poruke je i prema nekim od metodičkih načela: obogaćivanje djetetova iskustvenog svijeta, osoban odnos između vjeroučitelja i djeteta, vjeroučiteljevo autentično svjedočenje, strukturiranje didaktičkih programa, velika pažnja posvećena je dijalogu (govoru), razboritosti u uporabi vjerskih simbola, odgovornoj uporabi sveprisutnih audiovizualnih sredstava i izražajnih tehnika i aktivnosti (vodeći računa o spoznajnoj razini i poteškoći).

Svi metodički i didaktički zahtjevi koji stoje pred odgojiteljima i svim sudionicima odgojno-obrazovnog procesa u inkluzivno usmjerenoj nastavi i primjena didaktičkih pomagala stalan su izazov. ${ }^{24}$

\section{Vjeroučitelj u inkluzivnom obrazovanju}

Vjeroučitelji u školama izjednačeni su s ostalim učiteljima ${ }^{25}$ te imaju sličnu ulogu u poticanju i razvijanju inkluzivnog obrazovanja. Vjeroučitelji, između ostalog, imaju ulogu poticanja duha suradnje i zajedništva. ${ }^{26}$ Inkluzivno obrazovanje usmjereno je na postavljanje novih zadataka, metoda i oblika rada, uz poštivanje individualnih razlika svakog učenika. ${ }^{27}$ Za uspješnije i bolje provođenje uključivanja djece s teškoćama u inkluzivno obrazovanje treba postojati

\footnotetext{
${ }^{24}$ Usp. M. PRANJIĆ, Religijsko-pedagoško-katehetski leksikon, Zagreb, Katehetski salezijanski centar, 1991, 227-233.

${ }^{25}$ Usp. A. PERANIĆ, Vjeroučitelj između škole i župe, Riječki teološki časopis, 37 (2011) 1, 73-84, 78.

${ }^{26}$ Isto, 83.

${ }^{27}$ Usp. Karamatić Brčić, Implementacija i provedba..., 102.
} 
pozitivna interakcija između djece s teškoćama u razvoju i tipičnih vršnjaka. ${ }^{28}$ Vjeronauk osigurava religiozno učenje i religiozan odgoj učenika. ${ }^{29}$ Školski vjeronauk, zajedno s ostalim predmetima, podsjeća na jednakost pred Bogom, odnosno da su svi ljudi jednaki i jednakovrijedni bez obzira na različite sposobnosti, sklonosti i postignuća. ${ }^{30}$ Religioznim odgojem i obrazovanjem, koji ostvaruje nastava školskog vjeronauka, pruža se djeci podrška, pri čemu su ona usmjerena $\mathrm{k}$ zajedništvu. To pruža mogućnost da djeca s teškoćama uživaju temeljna prava i slobode ravnopravno s drugim učenicima i temelji se na jednakosti obrazovnih šansi za sve učenike prema njihovim sposobnostima. ${ }^{31}$

\subsection{Katehetske škole - vjerski i inkluzivni odgoj}

Nacionalni katehetski ured Hrvatske biskupske konferencije, u suradnji s Agencijom za odgoj i obrazovanje, već više godina organizira katehetske škole za vjeroučitelje koji rade u posebnim uvjetima odgoja i obrazovanja. Odgoj i obrazovanje djece s teškoćama u razvoju jedinstven su dio sustava odgoja i obrazovanja koji zahtijeva poseban pristup te posebno obrazovanje i edukaciju vjeroučitelja. U radu s učenicima s teškoćama kompetencije vjeroučitelja su izrazito važne. Stoga su sve teme dosadašnjih katehetskih škola proizašle iz konkretnih potreba inkluzije, vjeroučitelja, problema u radu s kojima se oni susreću, a prateći promjene koje se događaju u sustavu odgoja i obrazovanja.

Rad katehetskih škola bio bi nezamisliv bez suradnje s profesorima s Edukacijsko-rehabilitacijskog fakulteta koji su, svojim stručnim znanjem, iskustvom, praktičnim i konkretnim primjerima i savjetima, omogućili vjeroučiteljima bolje razumijevanje učenika $\mathrm{s}$ teškoćama, obogatili ih novim metodama i pristupima i omogućili im lakše svakodnevno snalaženje u razredima.

\subsection{Kurikulum za nastavni predmet Katolički vjeronauk}

Kurikulum za nastavni predmet Katolički vjeronauk za osnovne škole i gimnazije u RH polazi od temeljne pretpostavke da je vjerska pouka u izbornom konfesionalnom modelu jednako dostupna svima koji tu pouku izaberu, a da je učenje i poučavanje u stalnoj interakciji sa živom zajednicom ljudi vjernika. Svrha i opis predmeta donose da katolički vjeronauk učenicima želi omogućiti poznavanje i vrednovanje čovjeka i svijeta, da suvremena škola, pa tako i vjeronauk, zahtijevaju cjeloviti odgoj svakog učenika te ostvarivanje svih njegovih intelektualnih, moralnih i duhovnih mogućnosti. U svjetlu katoličke

\footnotetext{
${ }^{28}$ Usp. isto, 103.

${ }^{29}$ Usp. Filipović, Vjeronauk $u$ školi..., 259.

${ }^{30}$ Usp. isto, 251.

${ }^{31}$ Usp. Zakon o odgoju i obrazovanju u osnovnoj i srednjoj školi, 2018.
} 
vjere omogućava se svim učenicima, prema njihovim mogućnostima i sposobnostima, argumentirano i kritičko promišljanje i stjecanje spoznaja o čovjeku i svijetu te razvijanje i izgradnja vjerskih stavova i vrednota. Vjeronauk također ulazi u područje općeljudske kulture i u aktivan susret i dijalog s kulturom. Pri postavljanju odgojno-obrazovnih ciljeva učenja i poučavanja, kurikulum naglašava da sve što se želi razvijati, poznati, upoznati i pronalaziti tijekom procesa odgoja i obrazovanja, sve metode, metodički postupci te cjelokupan proces poučavanja treba ponuditi svakom učeniku. U učenju i poučavanju predmeta dodatna pozornost se stavlja na učenike s posebnim odgojno-obrazovnim potrebama (učenici s teškoćama i daroviti učenici) i učiteljevu planiranju kurikuluma usmjerenog na učenika. U takvom kurikulumu

»osobitosti/teškoće učenika zahtijevaju njima sukladne individualizirane/diferencirane postupke, ciljeve učenja, razinu usvojenosti odgojno-obrazovnog ishoda, opseg i dubinu sadržaja učenja, strategije i aktivnosti poučavanja kojima se žele ostvariti postavljeni ciljevi te načini vrednovanja i ocjenjivanja ostvarenih postignuća «. ${ }^{32}$

Trenutno stanje u provedbi i stanje u programu vjerskog odgoja djece i mladeži s posebnim potrebama te potrebne nastavne metode, metodičke postupke i oblike prilagođene inkluziji, s naglaskom na pozornost $u$ realizaciji korištenjem specifičnih katehetskih sredstava i pomagala (preporučujući neka sredstva i pomagala) u svom osvrtu donosi i Zvonka Matoic. ${ }^{33}$

Domene u organizaciji kurikuluma obuhvaćaju sva područja učenja, međusobno se prožimaju i nadopunjuju. Uključuju unutarpredmetnu i međupredmetnu korelaciju, povezanost s drugim predmetima i međupredmetnim temama, posebice društveno-humanističkim područjem. Vrednovanje u vjeronauku nije samo postignuće numeričke ocjene, nego je ponajprije usmjeravanje i poticanje učenika za procese razumijevanja, reflektiranja, kritičkog i kreativnog promišljanja. ${ }^{34}$

Programiranje vjeronaučne nastave slijedi programske sastavnice otvorenog kurikuluma, tj. promjenjive odrednice nastavnog procesa ili »didaktičko-metodičke varijable« kojima pripadaju: polazišna situacija, tj. vjeroučenik i vjeroučitelj u konkretnim sociogenim i antropogenim uvjetima u kojima se ostvaruje vjerski odgoj i obrazovanje; artikulacija odgojno-obrazovne svrhe vjeronaučne nastave s obzirom na njezin optimalno orisani vjerski odgojno-obrazovni horizont; vjeronaučni ciljevi i sadržaji kojima se to ostvaruje; metodički pristupi i

\footnotetext{
${ }^{32}$ Kurikulum za nastavni predmet Katolički vjeronauk za osnovne škole i gimnazije u Republici Hrvatskoj (Narodne novine, 10/2019), stavak F. Učenje i poučavanje predmeta, 345.

${ }^{33}$ Usp. Zvonka MATOIC, Program vjerskog odgoja djece i mladeži s posebnim potrebama, u Zvonka MATOIC (ur.), Srcem prema vjeri. Zbornik radova nacionalnog skupa o vjerskom odgoju djece i mladeži s posebnim potrebama, Zagreb, Nacionalni katehetski ured Hrvatske biskupske konferencije, 1999, 72-73.

${ }^{34}$ Usp. Kurikulum za nastavni predmet Katolički vjeronauk za osnovne škole i gimnazije u Republici Hrvatskoj (Narodne novine, 10/2019).
} 
mediji komuniciranja; vrednovanje postignutih rezultata u konkretnim vjeronaučnim susretima, u pojedinom godištu i u cjelini kurikuluma.

Načelo programske izvedbene prilagodbe podrazumijeva individualizirani i diferencirani pristup vjeronaučnom kurikulumu. Ti su pristupi pretpostavka djelotvornoga odgoja i obrazovanja učenika različitih dobi, različitih poteškoća i ostalih životnih okolnosti. Učeniku se pristupa kao jedinstvenoj i neponovljivoj osobi s njezinim prirodnim darovima, sklonostima, spoznajama, iskustvima, religioznim i duhovnim senzibilitetom, interesima i drugim različitostima. Ovako koncipiran program, po načelu otvorenoga kurikuluma, omogućuje prilagodbu kako darovitim učenicima, tako i učenicima s teškoćama u razvoju, te daje prostora slobodnom i kreativnom radu učenika i vjeroučitelja u izravnoj nastavi da bi se postigli optimalni odgojno-obrazovni ciljevi i vjeronauk bio istinski susret osoba, susret kojim se pridonosi ostvarivanju istinskoga životnoga zajedništva. ${ }^{35}$

\section{Dimenzija jednakosti u nastavi vjeronauka}

Temeljni model ponašanja i pristupanja drugome za kršćane je Isusov model ponašanja i pristupanja ljudima. On nije ovisio o njihovom vjerskom, ekonomskom, društvenom ili zdravstvenom statusu. Isus gleda pred sobom samo čovjeka i sve temelji na jednakosti svih pred svima. Svi izazovi koje pred nas postavlja suvremeno obrazovanje, jer želimo postati zemlja znanja, govore nam ne samo o važnosti obrazovanja, nego i o nužnosti i važnosti neodvojive odgojne sastavnice odgojno-obrazovnoga procesa. Izazovi suvremenog odgojno-obrazovnog procesa više naglašavaju obrazovanje, znanje i vještine jer globalizacija, sekularizacija, nagla industrijalizacija, različite interesne skupine te bespoštedna borba za profitom imaju za cilj razvijeno potrošačko društvo koje sve svodi na profit. Naprotiv, odgojno-obrazovni proces po kršćanskom poimanju je služenje čovjeku-učeniku koje promiče njegovo autentično dostojanstvo. ${ }^{36}$ Danas se, umjesto odgojno-obrazovne kulture zajedništva i tolerancije različitosti u svim svojim oblicima, stvara i promiče kultura produbljivanja različitosti i bespoštedne konkurencije. Negativni utjecaji društvenog okruženja, ratne rane, pojava religijskih fanatizama te diktat ekonomije stvaraju obrazovnu klimu koja opravdava sukobe zbog konkurentnosti jer pokazuju da samo za najbolje i najuspješnije ima mjesta. Svi su ostali, u svojim različitostima ili nedovoljno razvijenim sposobnostima, suočeni s nemogućnošću ostvarivanja istih početnih pozicija.

\footnotetext{
${ }^{35}$ Usp. R. J. STARRATT, Moral Education in the High School, Cultural Heritage and Contemporary Change, Series VI, Foundations of Moral Education, 3 (2006) 1-17.

${ }^{36}$ Usp. PAPA FRANJO, O odgoju, Split, Verbum, 2015, 149.
} 
Škola, obrazovanje i pedagogija, koji vode brigu o različitostima među učenicima, koji pokazuju osjetliivost na nejednakosti, povezani su s vrijednosnim usmjerenjem odgojnog djelovanja općenito. ${ }^{37}$ Za prevladavanje svih navedenih prepreka, koje nam danas donose objektivne i subjektivne poteškoće, potreban je odgoj, a onda i kršćanski odgoj koji se temelji na jednakim mogućnostima za sve sudionike-učenike u takvom dinamičnom i promjenjivom procesu.

Još jedan bitan izazov za odgoj općenito pa tako i kršćanski, vjerski odgoj i obrazovanje, jest stalna težnja za dijalogom. Dijalogom koji želi prevladati različitost $u$ početnim pozicijama za stjecanje znanja i vještina. Upravo takav doprinos odgoju žele dati religijska pedagogija i katehetika te vjeronauk, kršćanski odgoj, vjerski odgoj uopće. ${ }^{38}$

»Kultura inkluzivnog i konstruktivnog ophođenja s mnogolikošću imperativ je vremena na koji nastoje odgovoriti brojne društvene institucije, među kojima istaknuto mjesto zauzima škola.... ${ }^{39}$

Pozicija jednakih mogućnosti za sve (učenike) u kršćanskom, vjerskom odgoju ima svoje uporište u tome da je Bog Stvoritelj - Otac svih ljudi koji su međusobno braća. Takav odgoj stavlja u središte odgajanja cjelovitost i nepovredivost osobe sa svim njezinim potencijalima, ali i ograničenostima. ${ }^{40}$ Vjeroučitelji i vjeroučenici u uvažavaju razlika u psihofizičkom, mentalnom i psihosocijalnom razvoju djece i mladih pokazuju veoma veliku zauzetost $\mathrm{u}$ takvim nastojanjima. ${ }^{41}$

Konfesionalni vjeronauk u školi, kao dio odgojnog procesa, u zajedništvu sa svim sudionicima procesa odgoja i obrazovanja i svim faktorima koji utječu na taj proces, primarno dijalogizira s konkretnim čovjekom (učenikom) uvažavajući sve njegove odgojno-obrazovne potrebe. Školski vjeronauk djeluje i sudjeluje u odgojno-obrazovnim zadaćama škole, a u pluralnom društvu, gdje se različitosti promiču i poštuju, a sve s jednim zajedničkim ciljem: postizanja jedinstva u različitosti. ${ }^{42}$

\footnotetext{
${ }^{37}$ Usp. A. T. FILIPOVIĆ, Odnos vjeroučiteljica i vjeroučitelja u Hrvatskoj prema razlikama u razredu i nastavi, Crkva u svijetu, 51 (2015) 1, 7-34.

${ }^{38}$ Usp. R. RAZUM, Vjeronauk u školi u službi dijaloga i pomirenja, Bogoslovska smotra, 87 (2017) 3, 553-575.

${ }^{39}$ Filipović, Odnos vjeroučiteljica..., 8.

${ }^{40}$ Usp. Razum, Vjeronauk u školi..., 561-563

${ }^{41}$ Usp. Filipović, Odnos vjeroučiteljica..., 26.

${ }^{42}$ Usp. isto, 15.
} 


\section{Izazovi edukacijskog uključivanja učenika s teškoćama}

U izazovnim životnim situacijama češće se nađemo među sudionicima u konfliktu, nego među promicateljima mira i pomaganja drugima. Teško nam je odmaknuti se od svojega »ja« i od vlastite kulture pa odražavamo njezina prevladavajuća mišljenja i oponašamo njezinu praksu. Takva praksa u odgojno-obrazovnom sustavu nije uvijek naklonjena učenicima s teškoćama. Podržavajući viziju Božje budućnosti moramo izbjegavati nerazumijevanja i netolerancije te pružiti ruke svojoj braći i sestrama s druge strane. Moramo im dopustiti da nas izvuku iz zatvorenosti u vlastitu kulturu i njezine predrasude da bismo mogli Riječ Božju (na bilo koji način ispisanu) provesti u svakodnevno djelovanje. ${ }^{43}$ Upravo na ovakvim temeljima treba naći poticaje za rad s djecom $\mathrm{s}$ teškoćama na vjeronaučnoj nastavi u školi.

Budući da su vjeronauk i vjeroučitelji u potpunosti uključeni u redoviti sustav odgoja i obrazovanja, ${ }^{44}$ svi izazovi koji nastaju u uključivanju učenika s teškoćama u redovito školovanje zajednički su svima koji su u taj proces uključeni, ali pretpostavljaju, osim odgojno-obrazovne, i duhovnu dimenziju vjerskog poučavanja.

Vjeronauk u školskom sustavu Republike Hrvatske je konfesionalan (npr. rimokatolički, pravoslavni, islamski, protestantskog predznaka...). ${ }^{45}$ Stoga svaka vjerska zajednica svojom vjerskom poukom obuhvaća i odgovarajuće poučavanje djece s teškoćama koja su uključena u izabrani konfesionalni vjeronauk.

Cilj konfesionalnog modela vjeronauka je istaknuti odgojno-moralnu dimenziju, ne da se učeniku posreduju samo informacije o nekoj religiji, nego da obuhvati učenika u cijeloj njegovoj osobnosti, da može svestrano i kritički prosuditi svoj vlastiti život te da pritom usvaja opće, etičke i moralne norme njegujući vlastita vjerska uvjerenja, upoznajući i uvažavajući drugačija, svjesno graditi međuvjerski suživot sa svim ljudima. Područje vjerskog odgoja zahtijeva sustavno znanstveno i stručno istraživanje u našim konkretnim prilikama, stalan rad i napokon žurnu nabavu vjeronaučnih sredstava koja će omogućiti primjenu onoga što se načelno teorijski postavlja. ${ }^{46}$

Većina vjeroučitelja primarno je obrazovana i formirana na visokim učilištima i fakultetima za rad i djelovanje u redovitim uvjetima odgoja i obra-

\footnotetext{
${ }_{43}^{43}$ Usp. M. VOLF, Isključenje i zagrljaj, Zagreb, Steppress, 1999, 53-63.

${ }^{44}$ Usp. Zakon o potvrđivanju Ugovora između Svete stolice i Republike Hrvatske o suradnji na području odgoja i kulture (Narodne novine, 2/97); Ugovor između Vlade Republike Hrvatske i Srpske pravoslavne crkve u Republici Hrvatskoj o pitanjima od zajedničkog interesa (Narodne novine, 196/03); Ugovor između Vlade Republike Hrvatske i Evanđeoske (Pentakostne) crkve, Kršćanske adventističke crkve u RH i Saveza baptističkih crkava u RH o pitanjima od zajedničkog interesa (Narodne novine, 196/03); Ugovor između Vlade Republike Hrvatske i Islamske zajednice u RH o pitanjima od zajedničkog interesa (Narodne novine, 196/03).

${ }^{45}$ Usp. Zakon o pravnom položaju vjerskih zajednica (Narodne novine, 83/03).

${ }^{46}$ Usp. A. PAVLOVIĆ, Putovima vjerskog odgoja, Široki Brijeg, Suton, 2005, 71-74.
} 
zovanja. Stoga je Hrvatska biskupska konferencija uvidjela potrebu usvajanja specifičnih znanja i vještina za rad vjeroučitelja $s$ učenicima $s$ teškoćama te u suradnji s Edukacijsko-rehabilitacijskim fakultetom Sveučilišta u Zagrebu provela nekoliko ciklusa doškolovanja vjeroučitelja za rad u takvim posebnim uvjetima odgoja i obrazovanja. ${ }^{47}$ Uvidom u neposredan odgojno-obrazovni rad u razrednim odjelima gdje se provodi inkluzivni oblik rada s učenicima, vidljiv je napredak vjeroučitelja u pristupu, poučavanju, prilagodbi i individualizaciji vjerskih sadržaja.

Postoji mnogo školskih programa koji nisu dovoljno individualizirani za potrebe djeteta s teškoćama (dijete se prilagođava programu, a ne program djetetu) što može izazvati tjeskobu, agresivnost i slična ponašanja koja proizlaze iz preopterećenosti djeteta i nemogućnosti da zadovolji sve zahtjeve okoline. ${ }^{48}$

Interakcionistički pristup osobama $\mathrm{s}$ invaliditetom široj društvenoj zajednici predlaže da neposrednu okolinu oslobodi od prepreka za uključivanje takvih osoba u društvo, bile one u naravi (građevinske barijere) ili u svijesti i razmišljanju ljudi. Tim pristupom se naglašava veća uloga odgoja i obrazovanja. ${ }^{49}$ Ovakav pristup osobama s invaliditetom sukladan je mnogim temeljnim načelima kršćanske i općenito religijske zauzetosti za čovjeka. Vlastitim izborom da pomogne drugome, potrebitom, čovjek pomaže sebi u izgradnji vlastite osobnosti te tako djeluje na zajednicu čineći je boljom. Promjene u hrvatskom školstvu povezane uz edukacijsko uključivanje učenika s teškoćama i ostvarivanje njihovih prava ${ }^{50}$ postavljaju učiteljima zadaću s kojom se valja ozbiljno baviti te raditi na njezinoj primjeni. Poticaji i zadaće reformskih zahvata u školstvu, prilagodbe u nastavi, diferencirana nastava, prilagodba ishoda, prilagodba razina, opsega i dubine sadržaja, prilagodba pristupa, prilagodba vrednovanja, usklađenost svih navedenih sastavnica ${ }^{51}$ i prikaz primjera dobre prakse putem raznovrsnih raspoloživih medija te stalno osposobljavanje za rješavanje novonastalih situacija - aktivan su i trajan proces.

Model konfesionalnog vjeronauka u redovitom odgojno-obrazovnom sustavu hrvatskih škola u koji su uključena i djeca s teškoćama, relativno je nov, a dobio je pozitivne ocjene drugih europskih zemalja upravo zato što promiče vjersku toleranciju i nastojanje da se kroz univerzalne vrijednosti i prizmu općeprihvatljivih pozitivnih stavova promiče suživot sa svima.

\footnotetext{
${ }^{47}$ Usp. I. PAŽIN, Doškolavanje vjeroučitelja na Edukacijsko-rehabilitacijskom fakultetu Sveučilišta u Zagrebu, Katehetski glasnik, 14 (2009) 3, 162-163.

${ }^{48}$ Usp. S. GREENSPAN, Dijete s posebnim potrebama. Poticanje intelektualnog i emocionalnog razvoja, Lekenik, Ostvarenje, 2004, 365.

${ }^{49}$ Usp. LJ. IGRIĆ, Teškoće u razvoju i edukacijsko uključivanje, Hrvatska revija za rehabilitacijsko istraživanje, 40 (2004) 2, 151-164.

${ }^{50}$ Usp. LJ. IGRIĆ, Programi intervencija i neki okolinski čimbenici edukacijskog uključivanja, HNOS i djeca s posebnim potrebama, Dijete i društvo, 9 (2007) 1-2, 113-124.

${ }^{51}$ Usp. Đ. IVANČIĆ, Prilagodbe u radu s učenicima s teškoćama. Državni stručni skup za učitelje razredne nastave, Vodice, AZOO, 2016, 1-26.
} 


\section{Zaključak}

Zakon o odgoju i obrazovanju u osnovnoj i srednjoj školi (2018) prihvaća da djeca s teškoćama trebaju uživati temeljna prava i slobode ravnopravno s drugom djecom. Unatoč tome, zakonom propisana prava u praksi se ne ostvaruju tako. Osiguravanje primjerenih programa obrazovanja u lokalnim školama, potrebna razina podrške djeci, roditeljima, vjeroučiteljima i drugim učiteljima nije jednaka u svim sredinama, školama. Možemo li stoga govoriti o jednakim pravima svakog djeteta?

Budući da je temelj vjerskih osjećaja prihvaćanje, uvažavanje različitosti, empatija i ljudskost, značajna su sastavnica inkluzivne škole upravo vjeroučitelji, njihov pristup djeci $s$ teškoćama, način poučavanja i izrada primjerenih programa za nastavu vjeronauka. Bez obzira na konfesionalni predznak, školski vjeronauk, kao sastavni dio škole, prihvaća djecu s teškoćama i njihovu inkluziju. Stalnim stjecanjem novih znanja i vještina i vjeroučitelji, kao aktivni odgojitelji i sudionici odgojno-obrazovnog procesa, nastoje sve pozitivne spoznaje primjenjivati u svakodnevnom radu s učenicima.

Uvidom u literaturu i dosadašnja istraživanja inkluzivnog obrazovanja zaključeno je da su nužne promjene u kulturi zajednice i dosadašnjem funkcioniranju odgojno-obrazovnog sustava osiguravanjem dodatnih edukacija svih djelatnika, pa tako i vjeroučitelja radi poštivanja i uvažavanja raznovrsnih potreba svakog pojedinog djeteta i uz aktivno uključivanje svih važnih osoba $u$ njihovim životima. 


\section{Aleksandra Krampač Grljušić: - Dalibor Adžićc** - Aleksandra Gvozdanović Debeljak ${ }^{* * * * *}$ \\ Inclusive Education and the Dimension of Equality in the Religious Education \\ Summary}

The inclusive school is the result of various activities of the society. In order for children with developmental disabilities to be successfully involved in educational practice, it is important to develop the awareness of children about accepting and respecting diversity. By studying relevant literature, this paper presents legal provisions concerning the education of students with disabilities, the new and the old paradigm of disability and the inclusive education with an emphasis on the teaching of religion. The inclusive education is directed towards respecting the needs of every child. The new paradigm follows the Convention on the Rights of Persons with Disabilities, which first of all emphasizes the respect for human rights. Respect, appreciation and acceptance of diversity in the inclusive school is the foundation of each school subject and teacher. Since the religious education, through its program, emphasizes the importance and equality of all people, the religion teacher is an important creator of the curriculum for religious education that contributes to inclusive education.

Key words: inclusion, human rights, education, children with disabilities, school catechism.

(na engl. prev. Izabela Potnar Mijić)

* Aleksandra Krampač-Grljušić, PhD, Principal of Elementary School Ljudevit Gaj Osijek; Address: Krstova ulica 99, HR-31000 Osijek, Croatia; E-mail: a.krampac@yahoo.com.

** Dalibor Adžić, master of Religious Pedagogy and Catechetics (mag. paed. relig. et catech.) Education and Teacher Training Agency - Regional office Osijek; Address: Strossmayerova 6/1, HR-31000 Osijek, Croatia; E-mail: dalibor.adzic@azoo.hr.

*** Aleksandra Gvozdanović Debeljak, MEd, MAEdu in Special Education, PhD student, University of Zagreb, Faculty of Education and Rehabilitation Sciences; Address: Borongajska cesta 83f, HR-10000 Zagreb; Elementary School Ljudevit Gaj Osijek; Address: Krstova ulica 99, HR-31000 Osijek, Croatia; E-mail: agdebeljak@mefos.hr. 